\title{
THE INTERNATIONALISATION OF HIGHER EDUCATION: A NETWORKING BASED CONCEPTUAL FRAMEWORK
}

\author{
M.Miandy Munusamy ${ }^{+}$ \\ Azirah Hashim \\ Asia-Europe Institute, University of Malaya \\ 50603 Kuala Lumpur, Malaysia \\ +Corresponding author: miandy781121@gmail.com
}

\begin{abstract}
Internationalisation is an important worldwide phenomenon and a major trend in higher education. It is also one of the ways nations react to the impact of globalisation. There are multiple rationales that encourage various national governments, higher education institutions, international organisations and the private sector to proactively engage in educational services across national borders. Internationalisation theories have primarily focused on the internationalisation process in the business and economic dimensions, but since 1980s, it has influenced the structure of education and higher education systems. The network approach emphasises the benefits of developing long-term interactions with foreign markets, institutions and individuals. Networking also provides an important motivation for nations and higher education institutions to enrich international activities and expand their landscape, share best practices as well as transfer knowledge and balance risks. The study explores the Uppsala and network theories of internationalisation and its feasibility for examining networking in the internationalisation of higher education. It provides new insights into how the network model of internationalisation allows the influence of external actors or organisations to impact on the process of internationalisation of higher education. A conceptual framework on networking perspectives in internationalisation, which has the potential to contribute towards achieving internationalisation goals and the enhancing quality of higher education is proposed.
\end{abstract}

Keywords: Higher education, Internationalisation of higher education, Internationalisation theory, Network theory of internationalisation, Networking in internationalisation

\section{Introduction}

Internationalisation is an important worldwide phenomenon and a major trend in higher education. It is a phenomenon that arises from the impact of globalisation and relatively new in the education process. The phenomenon has led to a broad range of understandings and approaches. The globalisation of economies and societies as well as the increased importance of knowledge has influenced the development of the internationalisation of higher education. Substantial efforts have been carried out over the last decade to maintain the focus on internationalisation of higher education (Knight, 2015). Internationalisation is a term that is being used more and more to discuss the international dimension of higher education and, more widely, post-secondary education (Knight, 2004). Multiple rationales encourage various national governments, higher education institutions, international organisations and the private sector to proactively engage in educational services across national borders. 
The term 'internationalisation' had in the past generally referred to the international movement of firms and multinational companies (Welch \& Luostarinen, 1988). In the early 1970s, internationalisation became the main attention of firms to enhance their international operation (Flach \& Flach, 2010; Welch \& Welch, 1996). Besides that, collaboration with foreign markets and establishment of joint ventures to enhance efficiency in production also became major focuses of firms in the internationalisation process (Johanson \& Vahlne, 1990). In terms of education, the word "internationalisation" from the perspective of business or economy is generally interpreted as the participation of the higher education sector in foreign higher education markets, increases in revenue from international students and involvement in multilevel partnerships or networks with foreign higher education sectors for teaching and research purposes (Edwards \& Edwards, 2001). Stakeholders involved in higher education development believe that the internationalisation process could enhance networks and relationships between local and international higher education sectors (Jana, Laura, Dana, \& Clemens, 2017). Therefore, the internationalisation process of higher education has become an integral part of higher education providers to maintain the reputation, quality of higher education and their visibility in the international arena (Girdzijauskaite \& Radzeviciene, 2014). Furthermore, the concept of internationalisation of higher education has also been branded as a platform for increasing international students and producing competent graduates who are able to compete and survive in a globalised world (Robson \& Wihlborg, 2019).

In the last few decades, the networking perspective in the internationalisation process has developed as an administration instrument for the higher education sector. This is to increase its international involvement due to limitations in resources and finance. As a result, higher education providers and administrators share knowledge, technology, materials in order to stabilise the risks of international expansion (Girdzijauskaite, Radzeviciene, \& Jakubavičius, 2018). In the early 1980s, higher education institutions reacted quickly to international opportunities by creating networks for various activities such as student and staff mobility, courses and curriculum development, joint research and organisations. Knight (2007) has cautioned that diversification of higher education systems, language barriers and different cultures might be constraints to sustain and manage the networking in higher education internationalisation. Since the aim of networking in higher education cooperation is to achieve the four rationales of internationalisation, namely the academic, political, socio-cultural and economic, the solution to overcome the barriers should be the focus of higher education providers around the world (Knight, 2008a).

With regard to this, there is a necessity for higher education providers and stakeholders to focus on networking in internationalisation. Networking is a traditional style of relationship, very safe, will reduce risks and is a soft method of internationalisation (Girdzijauskaite \& Radzeviciene, 2014). Networking in higher education could also serve as a basis for multilevel partnership development and cooperation. Therefore, higher education stakeholders could adopt business type networking to gain more benefits from internationalisation through competition and cooperation (Girdzijauskaite et al., 2018).

In focusing on the network perspective on higher education internationalisation, the key aim of this article is to explore the network theory of internationalisation and its feasibility for networking in the internationalisation of higher education. The article will analyse the networking aspect of the internationalisation theory of the firm to understand the network model of internationalisation as developed by Johanson and Mattsson (1988). The applicability of this network theory for a conceptual framework for internationalisation of higher education 
will be discussed. The proposed conceptual model has prospects for synergising approaches, strategies and rationales for the internationalisation of higher education.

The article begins with an overview of internationalisation of higher education in terms of definition, approaches, strategies and rationales for internationalisation. This is followed by a review of internationalisation theories. Specifically, the Uppsala or process theory and network theory of internationalisation are described in detail. Next, the networking perspective in internationalisation and its connection to higher education internationalisation is discussed. Finally, a conceptual framework connecting the network theory of internationalisation and features of internationalisation of higher education is proposed.

\section{Internationalisation of higher education}

In the 1990s, internationalisation of higher education became a key topic worldwide (Teichler, 2004a; Yat \& Lo, 2009). In the globalised world, internationalisation of higher education is identified as a reaction to globalisation (Henard, Diamond, \& Roseveare, 2012; Altbach 2015). The responses constitute shifting interest from the social to more political and economic rationale, from collaboration to competition and the emergence of new dimensions such as virtual learning and transnational education (de Wit, 2013). The international dimension for higher education began to be nurtured as a principal agenda of higher education providers (de Wit, 2008). The definition and debate on internationalisation of higher education has been of much interest to many scholars in the past few decades (de Wit, 2013; Knight, 1994, 2008b). As a result, in accordance to internationalisation theory, James (2009) connected internationalisation of higher education to "organisational theory, marketing, strategic management, international management and education" (p. 28). Although the description is combined with internationalisation, a specific definition of the term has been identified. In the perspective of higher education, the term "internationalisation" covers a wide range of actions such as international relationships, multilevel partnerships, cooperative courses and projects, cross border education and international branch campuses (de Wit 2013; Knight, 2008; Pinna, 2009).

\section{Definition}

Arum \& Van de Water (1992) define internationalisation of higher education as various activities, projects and programmes that happen at higher education institutions (Knight 2004a). Knight (1994) introduced a broadly accepted definition of internationalisation of higher education as "the process of integrating an international and intercultural dimension into the teaching, research and service functions of the institution" (Knight, 1994, p. 3). The definition recognises internationalisation as a process and encompasses local and international characteristics (de Wit, 1999). Van der Wende (1997) suggested that internationalisation is "any systematic effort aimed at making higher education responsive to the requirements and challenges related to the globalisation of societies, economy and labour markets" (p. 20). Paige $\&$ Mestenhauser (1999) argued that this definition only stresses the influence of global forces and proposed internationalisation of higher education as "a complex, multidimensional learning process that includes the integrative, intercultural, interdisciplinary, comparative, transfer of knowledge-technology, contextual and global dimensions of knowledge construction" (p. 504). In the same year, an educationist, Wächter (1999), mentioned the importance of teaching and research and included functions of public service in the updated definition of higher education internationalisation. 
All these definitions in the early 1990s and late 1990s focussed on international activities or programmes in higher education institutions and showed the importance of higher education development. It is arguable whether the institutions of higher learning could achieve the goal of internationalisation without the involvement of stakeholders outside campus, especially the government and its agencies and departments. Beerkens (2004) has identified that the internationalisation of higher education is a regular policy issue that involves many parties from inside and outside campus in developed and developing countries. The argument concurs with the importance of integration and networks between all relevant stakeholders of higher education to internationalise higher education for mutual benefit. Knight (2015) came up with a comprehensive definition of internationalisation of higher education covering all parties including government, stakeholders and institutions. She defines internationalisation as "the process of integrating an international, intercultural, or global dimension into the purpose, functions or delivery of postsecondary education" Knight (2015, p. 3). As internationalisation requires a connection or networks between nations and various activities, therefore the term "process" underline the continuing efforts of internationalisation. "International" refers to inter-state or countries' relationships while "intercultural" deliberates on the existence of various cultures in the nations, communities and higher learning institutions. Lastly, to cover the wide range of higher education activities worldwide, the term "global dimension" is also used. Knight (2015) opines that the three terms complement each other and together depict the richness in the breadth and depth of internationalisation. The definition proposed by Knight (2015) on higher education internationalisation is broadly accepted for scholarly work. The evolution of this definition highlights quite significantly the importance of local and international elements' integration, which leads to the creation of relationships or networking in higher education. Knight (2013) emphasises that the term "networks" has described the international dimension and integration in higher education since the 1980s. Thus, networking and internationalisation can be refined for higher education internationalisation. However, the operation of the definition and creation of relationships as well as integration through networking needs approaches, strategies and an adequate rationale for internationalisation as the internationalisation process cannot stand on its own.

\section{Approaches to Internationalisation}

The vision to achieve the desired internationalisation of higher education varies according to the aims and objectives of nations, higher education institutions and stakeholders (Knight, 2008). The concept of internationalisation itself also consists of numerous techniques and approaches (Ramanathan, et al. (2012). The principles, significance and actions carried out during implementation of internationalisation are known as approaches and may vary according to the period of development stages (Knight, 2004). Besides that, approaches also provide a clear explanation of how internationalisation is recognised and executed. The four main approaches implemented to conceptualise internationalisation are the activity approach, competency approach, ethos approach and process approach (Qiang, 2003). These four approaches are only pertinent to higher learning institutions; therefore, assessment at the national government is necessary (Knight,1999). Nevertheless, five types of approaches which are applicable at national and institutions levels have been introduced by Knight (2008a). These are the programme, rationale, ad hoc, policy and strategy approaches. Each of these approaches is vital in developing policies and plans to execute an international dimension in higher education and to achieve the aim and mission of internationalisation. 


\section{- The programme approach}

The programme approach involves budget and money to organise activities, forums, conferences and programmes at the international level. This approach also underlines the importance of exchanges of students and staff and networking in internationalisation for teaching, curriculum development and research cooperation (Knight, 2008a). This approach can be materialised at both national and institutional level and a well-coordinated team is necessary to execute the programme approach (Qiang, 2003).

\section{- The rationale approach}

The second approach, the "rationale" approach, is most imperative for national-level higher education internationalisation (Knight, 2008a). Initially, Knight (2008) mentioned that effective rationale approaches are competitiveness, human resources development, strategic alliances, income generation, commercial trade, nation- building, and community development. However, recently scholars adopted four imperative rationales at national and institutional level, which are socio-cultural, political, economic and academic (de Wit, 2002, 2011 \& Farina et al., 2015).

\section{- The ad hoc approach}

The third approach, the ad hoc approach, refers to quick reactions to the internationally available chances in higher education (Knight, 1999). This is a loose approach as there is no right or wrong direction in choosing the opportunities that are available. Therefore, the national government and institutions participate individually in numerous programmes, projects and activities internationally when obtainable and applicable (Knight 2008a).

\section{- The policy Approach}

The policy approach defines the importance of policies which emphasise the significance of the international dimension in higher education (Knight, 2008a). The policies may be established or introduced by various stakeholders such as higher education departments, qualifications agencies, foreign affairs, immigration departments, international trade ministries and other relevant ministries, departments and agencies involve directly and indirectly in higher education development.

\section{- The strategic approach}

Lastly, the strategic approach involves tangible actions and plans carried out by national governments, agencies and higher education institutions to execute effectively the process of internationalisation of the higher education. This approach inevitably assists all parties involved in higher education internationalisation to achieve the goal and objectives of internationalisation (Knight, 2008a).

Although these five approaches are applicable at both national and institutional level, Knight (2008a) agreed that institutions may have different guiding principles on internationalisation. Therefore, she recommends five tolerable additional approaches, namely, activity, outcomes, process, cross border and ethos. The important point noted in applying various approaches in higher education internationalisation is the linkages or connection between stakeholders involve in internationalisation activities. Strong networking or inter-connection is considerably required to sustain and maintain the approaches in internationalisation as it brings together all the interested parties to internationalise higher education at national and institutional level (Knight, 2004a). 


\section{Strategies for internationalisation}

Elements related to internationalisation of higher education are described as mechanisms, facilitators, activities, challenges, factors and strategies (Knight, 1997, 1999; Qiang, 2003; Zolfaghari et al., 2009).The strategies for internationalisation of higher education at national and institutional level are varied and implemented according to needs and objectives (Knight 1997; 1999; Qiang, 2003). At institutional level, operational strategies are used for international integration of research, teaching, services for international students and policies for administration (Zolfaghari et al. 2009). The strategies for internationalisation are generally adopted as a living document or policy statements to encourage active participation of all relevant parties in higher education internationalisation (de Wit, 2013). Consequently, Knight (2015) supports that internationalisation itself can be a robust strategy to enrich international, intercultural and global dimension in teaching and research, knowledge transfer and community services around and within the higher education environment.

Fundamentally, internationalisation strategies are mainly dedicated to inter-institutional agreements, networking in terms of research and teaching, recruitment of international students and establishment of branch campuses and other international activities (Harman, 2005; Knight, 2008a; Shahijan, Rezaei, \& Preece, 2016). For instance, Asian countries such as Singapore emphasise internationalisation strategies to improve domestic higher education (Nguyen, Vickers, Ly, \& Tran, 2016). In China, the strategy is to export Chinese knowledge and in Hong Kong, the establishment of international networks and attracting mainland Chinese students become the main internationalisation strategy (Pretor Fok, 2007).

\section{Rationale for internationalisation}

Various motivations and rationales influence the field of higher education and internationalisation of higher education (Kireçci et al., 2016; Knight, 1997; Rahim \& Nizam, 2013). Jiang (2010) has identified that the rationale for internationalisation referred to motivations for assimilating an international dimension into higher education. Knight (2004, 2007) states that a clear set of rationales delivers benefits and estimated outcome from the internationalisation efforts. Knight $(1997 ; 2004)$ and (de Wit, 2013) put forward four vital rationales for internationalisation of higher education process. These are socio-cultural, political, academic, and economic. There are various other rationales such as international security, economic competitiveness and financial improvement which have been emphasised by scholars, however Qiang (2003) supported that the four rationales as identified by Knight (1997; 2004) and (De Wit, 2013) have major effects for internationalisation of higher education at national and institutional level (Wadhwa \& Jha, 2014).

\section{- The political rationale}

Firstly, the issues relate to stability, security, harmony, philosophical influence and sovereignty are major parts of the political rationale (Jiang, 2010; Qiang, 2003). De Wit (1998) and Qiang (2003) suggested the involvement of national government, higher education institutions, private sector and inter-governmental organisations should be highly considered to sustain and maintain the political interest of a nation.

\section{- The economic rationale}

Secondly, the economic rationale refers to the contribution of skilled graduates for the local and international market by internationalised higher education and income benefit from trade relations and international students (Qiang 2003). For instance, in the United Kingdom higher 
education system, international students fees and living expenses generating immediate revenue for the national government and higher education institutions (Chankseliani, 2017).

\section{- The academic rationale}

Thirdly, the aims and purposes of delivering higher education are represented by the academic rationale (Qiang 2003). Therefore, enhancement of teaching and learning process as well as achieving excellence in research and scholarly activity has become a major focus of this rationale (Jeptoo \& Razia, 2012; Qiang, 2003).

\section{- The socio-cultural rationale}

Finally, the socio-cultural rationale emphasises the imperative of sustaining one's own national culture and language as well as the importance of understanding other foreign cultures and languages for the benefit of internationalisation. Inter-cultural understanding and a strong national cultural identity are important factors needed for mutual respect, to build a peaceful society and to acquire international skills for global markets (Jeptoo \& Razia, 2012; Salas, 2014; Wadhwa \& Jha, 2014).

In actual fact, Knight (2008a) and De Wit (1999) stated that the political and economic rationales have become push factors for internationalisation of higher education at national and institutional level. Knight (2008a) asserted that strategic alliance under the political rationale is a significant element that should be stressed by the national government, higher education stakeholders and institutions for international cooperation and multilevel partnerships through networking. Strategic alliances are able to become a cooperative approach (Teichler, 2009) and connect national borders of higher education cooperation as a challenge to globalisation (Wendy, 2006). This element is also strongly backed by the academic rationale (De Wit, 2011). The academic rationale contributes to hindering competition among competitors in the field of higher education by creating strategic alliances (Kehm \& Teichler, 2007). Networks play a crucial role in creating a strategic alliance between nations and higher education institutions. According to Knight (2004), networks often have relevant and strategic objectives in internationalisation. Flach \& Flach (2010) supported this and stated that networking through internationalisation can strengthen the interaction between the parties involved in the process. Subsequently, a strong relationship in networks will maximise the knowledge of internationalisation and will lower the networks' complications (Johanson \& Kao, 2010). Baturina \& Terentyeva (2019) proposed that higher education institutions should identify new types of relationships with external actors or organisation to fulfil the resources limitation, to enhance overall performances and competitiveness of higher education. Therefore, the connection between internationalisation theory, networking in internationalisation and higher education internationalisation are explored to identify a suitable conceptual framework.

\section{Internationalisation}

In the early 1970s, the international movement of firms and multinational companies is largely known as internationalisation (Welch and Luostarinen, 1988). Welch and Luostarinen (1988) suggested a broadly accepted definition of internationalisation as "the process of increasing involvement in international operations" (p. 36). The definition indicates high participation and creation of connections or networks outside the country. Therefore, a country's economic, political and social development does not take place in a closed boundary. It also needs to tie in with an international platform. However, Melin (1992) and Welch and Welch (1996) argued that this definition only focused on operations and administrative issues. They recommended 
that strategy elements should be linked with internationalisation theory at theoretical and operational levels. Melin (1992) claimed that the internationalisation process at both conceptual and practical levels is complex, diverse and not stable. As a result, he suggested long-term comprehensive research and approaches to fully understand the process of internationalisation.

There are four major internationalisation theories that have been proposed by scholars. These are the Uppsala or process theory, eclectic/economic theory, network theory and international entrepreneurship theory. The four theories have played significant roles in business and firms' internationalisation (Flach \& Flach, 2010). Flach and Flach (2010) have also identified that the internationalisation process has influenced the structure of education and higher education system around the world. Dunning (1980) introduced the eclectic/economic theory and emphasises three important advantages. These are ownership advantages, locational advantages and internalisation advantages (Dunning, 1980) which underline the importance of internal factors such as internationalisation at home, organisation ability, cost incurred (Girdzijauskaite \& Radzeviciene, 2014; Girdzijauskaite et al., 2018) and Foreign Direct Investment (FDI) (Ruzzier, Hisrich, \& Antoncic (2006) as well as localisation (Edwards \& Edwards, 2001). Besides that, the international entrepreneurship theory features the importance of integration of entrepreneurs in internationalisation (Ruzzier, Hisrich, \& Antoncic (2006). Ruzzier, Hisrich, \& Antoncic (2006) claimed that international entrepreneurship theory is more applicable to Small Medium Enterprises (SME), which emphasises the involvement of individual entrepreneurs. Arguably, both theories do not match the approach, rationale and strategy for internationalisation of higher education. As a result, this article explores the Uppsala theory and network theory of internationalisation to conceptualise a framework to support the higher education development as it widely accepted and useful for internationalisation of higher education (Flach \& Flach, 2010; Girdzijauskaite \& Radzeviciene, 2014; Girdzijauskaitė et al., 2018; Girdzijauskaitè, Radzevičienè, \& Jakubavičius, 2019; James, 2009).

\section{Uppsala theory of internationalisation}

In 1975, Johanson and Wiedersheim-Paul, through their study on four Swedish firms, concluded that firms required incremental steps to internationalise (Johanson and Vahlne, 2009). Two years later, Johanson and Vahlne (1977) advanced their findings and introduced the Uppsala theory of internationalisation. The theory describes the features of the internationalisation process of a firm. The model also focuses on interactive relationships rather than economic benefits (Edwards \& Edwards, 2001). In addition to its features, the model stresses the state aspect (market commitment and market knowledge) and change aspect (current business activities and commitment decision) (Johanson \& Vahlne, 1977). In terms of higher education internationalisation, the two aspects are applicable as international higher education cooperation is developed stage by stage through risk understanding, opportunities and benefits (Girdzijauskaitè et al., 2019). The internationalisation process in higher education will start with mobility of international students and be followed by a more comprehensive commitment such as exchange of staff, knowledge and technology transfer, curriculum and programme development as well as the establishment of international branch campuses (Girdzijauskaite \& Radzeviciene, 2014). However, Edwards and Edwards (2001) expressed that higher education institutions that adopted the Uppsala model need to embark wisely in incremental steps of internationalisation process by examining the risks and increase experiences before deciding on big commitments such as the establishment of branch campuses. 
Girdzijauskaite et al. (2019) mentioned that the Uppsala model of internationalisation comprises four components to enter foreign markets. These are exporting, licensing production, joint ventures and sole ventures. The term (1) exporting refers to international students studying abroad or pursuing their higher education in different country; (2) licensing production means twinning or franchising programmes such as $1+2$ or $2+2$ study period (local + abroad); (3) joint ventures and (4) sole ventures refer to establishment of branch campuses either through partnerships or wholly-owned branch campuses (Healey, 2008). It is clear that Uppsala model emphasises the economic perspective. The impact on other rationales for internationalisation such as the socio-cultural, politic and academic is lacking. Girdzijauskaite et al. (2019) urged that the Uppsala model originally established to explain the internationalisation process in firms, industries and business. Edwards and Edwards (2001) concluded that internationalisation of services sector such as higher education providers may follow different trails to fulfil the rationale for internationalisation to themselves, governments, students and societies. James (2009) also agreed that this model is less appropriate to knowledge-intensive and business service industries including the higher education sector. As such, there is a need for identifying a more appropriate internationalisation theory, which can accommodate the approaches, strategies and rationale for internationalisation. Through recent empirical research, Johanson \& Vahle proposed that the re-examined Uppsala theory as a network model of internationalisation is more applicable and can meet the rationale for internationalisation (Johanson \& Vahlne, 2009).

\section{The network theory of internationalisation}

In 1988, Johanson \& Mattsson established a network theory of internationalisation by exploring the Uppsala model of Johanson \& Vahlne $(1977,1990)$. The network model of internationalisation provides a platform for external or outsiders influences on the internationalisation process of firms or business (Johanson and Mattsson 1988). The connection between two or more businesses is defined as a network and the relationships between the businesses or firms is known as shared players (Blankenburg Holm, Eriksson, \& Johanson, 1996). Networking in internationalisation is vital for entering foreign markets and also to strengthen the position of firms or organisation in the market (Johanson and Vahlne 2009). Networking also emphasises the importance of organisation relationships and advantages gained (Girdzijauskaite et al., 2019). It also allows for continuous learning in the networks (Ruzzier et al., 2006). Networking in internationalisation also provides a valuable platform to gain the information of the existing market through exchanges and communication with existing network members and non-members from outside of the networks. This is an additional feature of the extended version of the Uppsala theory. In the existing model, market knowledge is acquired from experiences in the networks (Johanson and Vahlne 2009). It is confirmed that networking is an avenue for knowledge and market information (Chetty and Campbell-Hunt 2003; Masum and Road 2012; Rastorgueva 2014; Welch and Welch 1996) which allows for international expansion, penetration and strong relationship among partners (Johanson \& Mattsson, 1988) as well as international integration (Coviello \& Munro, 1997).

In terms of international cooperation, the network is also known as a form of multilateral governance structure. Mori (1999) expressed that in networking, the multilateral governance allows the connected parties to perform and interact freely within the structure and flexibly outside the structure. He also claimed that inter-governmental organisation such as the AsiaPacific Economic Cooperation (APEC) has integrated the network theory for internationalisation process among the members including in higher education cooperation. The relationship between members in the inter-governmental organisations such as APEC, the 
Asia Europe Meeting (ASEM) and Organisation for Economic Cooperation Development (OECD) has become closer and it is always based on mutual learning and trust as well as knowledge commitment (Johanson \& Kao, 2010; Masum \& Road, 2012). The network approach in international cooperation also helps to develop long-term relationships with individuals and organisation worldwide (Hadley \& Wilson, 2003). Ruzzier, Hisrich, \& Antoncic (2006) stated that networking in internationalisation could be applied to overcome knowledge, technology, resources and trust issues in the international market.

The important element featured by the network model of internationalisation is the bridging mechanism (Mtigwe, 2006) which permits continuous internationalisation and allows multilateral influences on international decision making (Johanson and Mattsson 1988; Johanson and Vahlne 1990). Networking in internationalisation is divided into three types of relationships. Firstly, a formal relationship with financial commitment (Rastorgueva, 2014), secondly, an informal relationship with loose contacts between members and relationship with other networks members (Birley, 1985) and finally, an intermediary relationship that relates to influences of third party and indirect connections (Ojala, 2009). There are three vital rationales or motivations for networking in internationalisation. These are resource and knowledge sharing, mutual learning and strengthening positions against competitors in the market (Girdzijauskaite \& Radzeviciene, 2014). According to Girdzijauskaite et al. (2019), the existing government to government (G-to $G$ ) cooperation between nations will innovate to multilateral partnerships if there are complex activities or actions and multifaceted partners. This process always happens in higher education internationalisation because it involves various activities, projects and programmes amongst several parties internally and internationally. A strong networking between nation and higher education institutions is required to internationalise higher education. Therefore, it could be deduced that the network theory of internationalisation is the most appropriate one to apply to higher education internationalisation at national and institutional level.

\section{Networking for internationalisation of higher education}

There are multifaceted administration and bureaucracy, vibrant cooperation and vast networking dimensions in higher education sector consisting stakeholders at the ministries, departments, agencies and higher education institutions (Szyszlo, 2016). One of the major factors affecting the internationalisation of higher education is the recruitment of international students followed by the benefits for economic and socio-cultural rationale. International networking plays a crucial role for higher education institutions to work closely with their international partners to increase international students. The bridging mechanism characteristic of networking in internationalisation could become a very useful strategy and approach to increase international students. The market information and penetration tactics are also a valuable tool of networking in internationalisation to achieve the desired international students. The intermediary function of networking has assisted higher education providers to gain information on international students around the world and get them to enrol in higher education institutions (Sarkar \& Perényi, 2017).

The nations involved in the massive internationalisation of higher education emphasises the development of policies and action plans for international cooperation in higher education (Kristensen \& Karlsen, 2018). Institutional networking between local and foreign higher education institutions is the fastest way to implement the internationalisation approaches and strategies (Mader et al., 2013). Girdzijauskaite \& Radzeviciene (2014) mentioned that, currently, the higher education institutions' networking in internationalisation is an encouraging type of international cooperation, which creates a pathway to enter the foreign 
higher education market. The higher education institutions can also build its international profile through international networking (Girdzijauskaite \& Radzevičienè, 2013) to benchmark the quality of higher education, programmes accreditation and curriculum standard. The multilateral governance structure of network theory is most relevant and appropriate to enhance the international cooperation between higher education institutions. This element allows higher education institutions to build a relationship with its partner institutions directly and indirectly (Mori, 1999). It also creates a strategic and multilevel partnership between partners that can maximise the approach, rationale and strategies for internationalisation of higher education (Kristensen \& Karlsen, 2018).

Strategic alliances through networking is an important tool to establish relationships and to gather market information and recent development in the higher education internationalisation worldwide. Alliances play a dynamic role for higher education institutions cooperation and collaboration in the field of higher education and other international activities (Khalid, Ali, Islam, Khaleel, \& Shu, 2017) such as student and staff exchanges, consultation and joint research. Strategic alliances under the term networking provide an avenue for sharing of knowledge, technology, best practices and resources as well as equal power (Girdzijauskaite \& Radzevičiené, 2013) to enhance the quality of higher education and produce marketability graduates. The network theory of internationalisation plays an important role in the establishment of foreign branch campuses. Girdzijauskaite et al. (2019) supported this and stated that the nature of the network theory of internationalisation has the potential to increase the development of branch campuses. The establishment of foreign branch campuses is in line with the network theory of internationalisation characteristics, which emphasises entering foreign markets and strengthening position (Johanson \& Vahlne, 2009). The establishment of branch campuses brings benefits for local and international stakeholders. In terms of local stakeholders, it provides opportunities to have international students, scholars, programmes, curriculum and intercultural understanding as well as a venue for local students to pursue their higher education without travelling abroad. Meanwhile, for international stakeholders the branch campuses brings revenue and international collaboration (de Wit, 2013) as well as partnerships with local higher education providers (Girdzijauskaite \& Radzeviciene, 2014).

\section{Conceptual Framework}

From the above, it appears that the approaches, rationales and strategies for higher education internationalisation are satisfactorily and substantially supported by the network theory of internationalisation and networking in internationalisation elements and motivations. The approaches, rationales and strategies are also supported by several elements of the Uppsala theory. Therefore, it seems appropriate to propose a conceptual framework as shown in Figure 1 for higher education internationalisation through networking and internationalisation. The conceptual framework suggests that the approach, strategy, and rationale for internationalisation are explained by networking in internationalisation through international expansion, market penetration, international integration, multilateral governance, bridging mechanism, partnership and strategic alliances. The definition of the internationalisation of higher education as proposed by Knight (2015) is sufficiently emphasised by the seven elements of networking. The three important terms of internationalisation of higher education, (1) international, (2) intercultural and (2) global dimension are also reinforced by the definition of network theory of internationalisation that allows for the integration of internal and external forces for internationalisation through networking. 


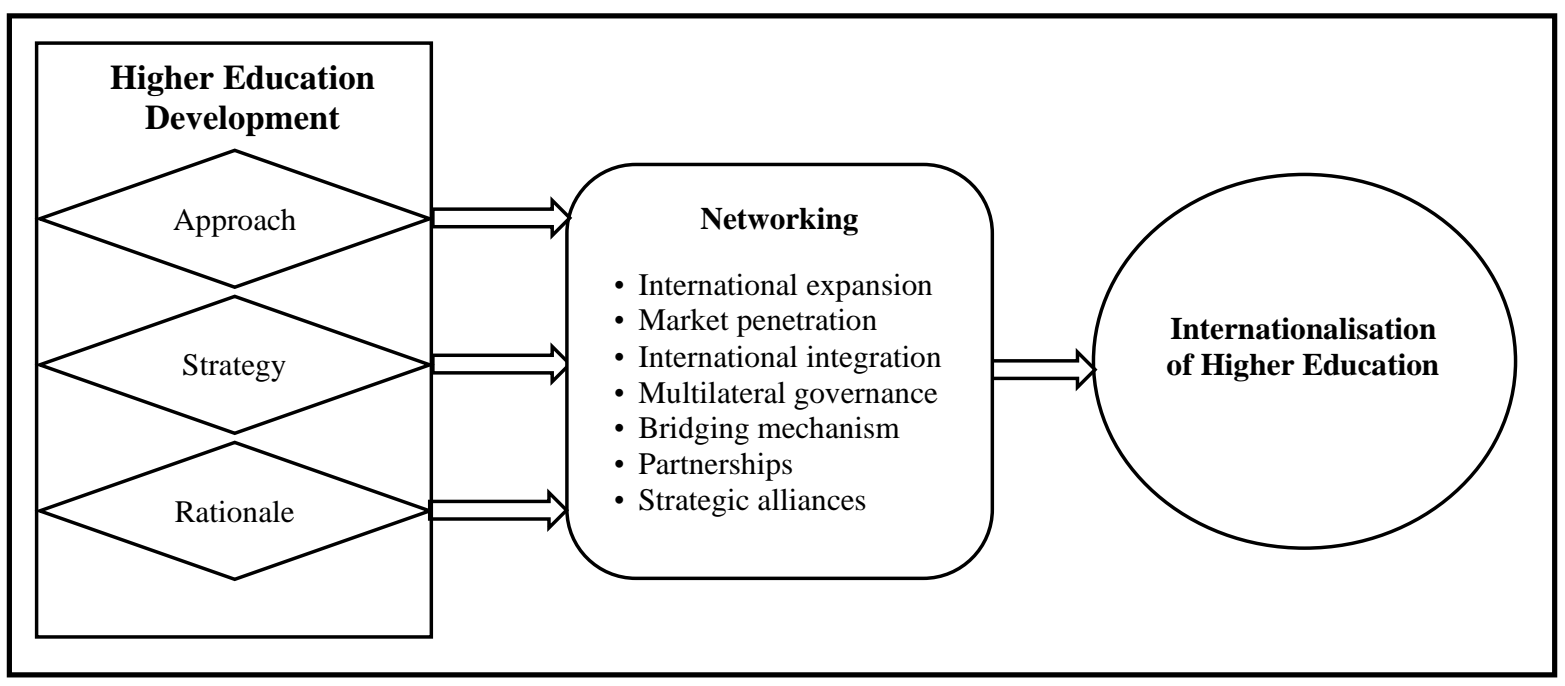

Figure 1: Conceptual Framework

The networking components, expansion, partnerships and strategic alliances could explain and support the approaches to internationalisation (programme, rationale, ad hoc, policy and strategic approach). These components can also assist the higher education system to implement imperative internationalisation activities such as conferences, joint research, curriculum and courses development and staff and students exchanges (Kristensen \& Karlsen, 2018). For instance, in the case of Malaysia, the higher education internationalisation at university level has become the bridge between local and international scholars to share their expertise and knowledge for higher education development (Mohd Ismail \& Doria, 2012). Sanders (2018) believes that internationalisation of higher education could become a bridge between states, regions and higher education institutions. Meanwhile, market penetration and international expansion are important components of networking that can connect strategy for internationalisation of higher education to increase international students and establish branch campuses abroad (Knight, 2004a). For example, Malaysia encourages foreign institutions to establish branch campuses (Chan, 2013) to fulfil Malaysian students' demand and to attract international fee paying students from the region (Healey, 2008). Thus, in 2013, eight international branch campuses from Australia and the United Kingdom (UK) were established in Malaysia through the strong networking carried out (Mohd Ismail \& Doria, 2014). Girdzijauskaite et al., (2019) stated that the University of Reading from UK developed strong networks with local Malaysian partners and finally established a branch campus in Malaysia.

Consequently, all the seven components of networking in internationalisation are vital in supporting the rationale for internationalisation of higher education. Firstly, international expansion and market penetration relate to economic rationale. The major contribution of these two components for economic rationale are fees paying international students, economy growth, financial incentives and labour market (Knight, 2008a). Secondly, international integration supports the socio-cultural rationale for the improvement of intercultural understanding and maintaining the national cultural identity as well as understanding foreign language (Qiang, 2003). Thirdly, the partnership and strategic alliance components influence the academic rationale for staff and student exchanges, research collaboration, teaching and curriculum and courses development (Wihlborg \& Robson, 2018). Lastly, the multilateral governance and bridging mechanism support the political rationale. These two components encourage relationship among nations for trade purposes, inter-institutions agreements and 
cross border higher education (Knight, 2008c). For the Malaysian case, networking in internationalisation creates an important alliance for cooperation and collaboration in the field of higher education between nations and between higher education institutions. It also attracts international students to Malaysia (Arokiasamy, 2011). Additionally, it also plays a major role in assisting the Malaysian higher education system to be recognised and become more visible and provides opportunities for twinning and franchised programmes (James, 2009). The Lim Kok Wing University of Creative Technology, for example, has signed an agreement with Curtin University of Australia and offers Australian degrees to their students. This agreement has attracted many international students to study in Malaysia at the Lim Kok Wing University of Creative Technology (Russell, 2015). The Monash University from Australia established a branch campus in Malaysia in 1990 which has helped to generate revenue from tuition fees and research commercialisation (Girdzijauskaite \& Radzeviciene, 2014). The development of higher education in Malaysia through networking in internationalisation shows that it supports the strategy, approach and rationale for internationalisation of higher education.

The connection between the approach, strategy and rationale of higher education development and the components of networking can be a valuable pathway for comprehensive internationalisation of higher education in nations around the world. The conceptual framework is significant for higher education internationalisation as firstly, it can be used at national and higher education institutions level. Secondly, it is applicable for public and private higher education providers and can facilitate policy and action plans development. Finally, it can assist nations to increase international students and enhance the cross border higher education.

\section{Conclusion}

The main aim of the article is to explore the network theory and Uppsala theory of internationalisation as well as their feasibility for networking in the internationalisation of higher education. The literature findings illustrate that both theories, the Uppsala and the network theory of internationalisation have employed networking elements for internationalisation (Johanson \& Mattsson, 1988; Johanson \& Vahlne, 1990). Therefore, there is a strong connection between internationalisation theories and conceptualisation of internationalisation of higher education in terms of definition, approaches, rationale and strategies. The definition of internationalisation of higher education as proposed by Knight (2015) that covers the functions of the national government, higher education institutions and foreign higher education is widely accepted and useful for networking in internationalisation. The approaches, rationale and strategies for internationalisation are supported by the networking perspective in the internationalisation process, which has advanced and been innovated as a management tool for higher education internationalisation (Girdzijauskaite et al., 2018). Thus, the seven elements of networking as suggested in the conceptual framework support networking in internationalisation as well as the approach, rationale and strategy for internationalisation of higher education in the case of Malaysia. The major contribution of the network theory of internationalisation is the establishment of branch campuses and recruitment of international students. Therefore, the network theory of internationalisation can be seen to be feasible and appropriate for the internationalisation of higher education. The proposed conceptual framework will be useful for national governments and higher education institutions to achieve the goal of internationalisation and to enhance the quality of higher education. 


\section{Acknowledgement}

The paper acknowledges the support of the Jean Monnet Center of Excellence project (Project Number: 586907- EPP-1-2017-1-MY-EPPJMO-CoE).

\section{References}

Altbach, P. G. (2015). Perspectives on internationalizing higher education. International Higher Education, 27, 6-8.

Arokiasamy, A. R. A. (2011). An analysis of globalization and higher education in Malaysia. Australian Journal of Business and Management Research, 1(9), 73-81. Retrieved from http://www.ajbmr.com/articlepdf/AJBMR_19_22i1n9a8.pdf

Baturina, O. A., \& Terentyeva, T. V. (2019). Networking of strategic partnerships in higher education: Prerequisites and readiness of universities Introduction. Revista de Ciencias Sociales Y Humanidades, 4(18), 163-169. https://doi.org/10.1017/CBO9781107415324.004

Beerkens, H. J. (2004). Global opportunities and institutional embeddedness : Higher education consortia in Europe and Southeast Asia. Netherlands: Centre for Higher Education Policy Studies. https://doi.org/10.1017/CBO9781107415324.004

Birley, S. (1985). The role of networks in the entrepreneurial process. Journal of Business Venturing, 1(1), 107-117. https://doi.org/10.1016/0883-9026(85)90010-2

Blankenburg Holm, D., Eriksson, K., \& Johanson, J. (1996). Business networks and cooperation in international business relationships. Journal of International Business Studies, 27(5), 1033-1053. Retrieved from http://www.jstor.org/stable/155580

Chan, S. J. (2013). Internationalising higher education sectors: Explaining the approaches in four Asian countries. Journal of Higher Education Policy and Management, 35(3), 316329. https://doi.org/10.1080/1360080X.2013.786854

Chankseliani, M. (2017). Four rationales of HE internationalization: Perspectives of U.K. universities on attracting students from former Soviet countries. Journal of Studies in International Education, 1-18. https://doi.org/10.1177/1028315317725806

Chetty, S., \& Campbell-Hunt, C. (2003). Explosive international growth and problems of success amongst small to medium-sized firms. International Small Business Journal, 21(1), 5-27. https://doi.org/10.1177/0266242603021001719

Coviello, N., \& Munro, H. (1997). Network relationships and the internationalisation process of small software firms. International Business Review, 6(4), 361-386. Retrieved from https://ac.els-cdn.com/S0969593197000103/1-s2.0-S0969593197000103main.pdf?_tid=c0fa9e60-5f2c-4cd7-895261f17aa608a9\&acdnat=1551836102_2253872aad34dc981e939dba9999e30f

de Wit, H. (1999). Changing rationales for the internationalization of higher education. International Higher Education, 15, 2-3. https://doi.org/10.6017/ihe.1999.15.6477

de Wit, H. (2008). Globalisation and internationalisation of higher education. International Journal of Educational Technology in Higher Education, 8(2), 241-248. Retrieved from http://ezproxy.pacific.edu/login?url=http://search.ebscohost.com/login.aspx?direct=true\&db $=$ ehh $\& \mathrm{AN}=69540382 \&$ site $=$ eds-live

de Wit, H. (2011). Globalisation and internationalisation of higher education. International Journal of Educational Technology in Higher Education, 8(2), 241-248. 
https://doi.org/10.7238/rusc.v8i2.1247

de Wit, H. (2013). An introduction to higher education internationalisation. (H. de Wit, Ed.). Milan, Italy: Vita E Pensiero. Retrieved from http://citeseerx.ist.psu.edu/viewdoc/download?doi=10.1.1.905.8413\&rep=rep1\&type=pdf

Dunning, J. H. (1980). Toward an eclectic theory of international production: Some empircal tests. Journal of International Business Studies, 11(Spring Summer), 9-31. Retrieved from http://www.palgrave-journals.com/jibs/journal/v11/n1/abs/8490593a.html

Edwards, R., \& Edwards, J. (2001). Internationalisation of education: A business perspective. Australian Journal of Education, 45(1), 76-89. https://doi.org/10.1177/000494410104500107

Farina, Y., Koo, Y. L., \& Yazrina, Y. (2015). Internationalisation of higher education: Insights from Malaysian Higher Education institutions. Pulau Pinang, Malaysia: Penerbit Universiti Sains Malaysia.

Flach, L., \& Flach, L. (2010). Institutional theory and the internationalization of higher education in South America: the Brazilian Case. Journal of International Business and Economy, 11(1), 26.

Girdzijauskaite, E., \& Radzeviciene, A. (2014). International branch campus: Framework and strategy. Procedia - Social and Behavioral Sciences, 110, 301-308. https://doi.org/10.1016/j.sbspro.2013.12.874

Girdzijauskaite, E., \& Radzevičienè, A. (2013). Opportunities of competitiveness of a latecomer university. In 16th Conference for Junior Researchers ,,Science - Future of Lithuania“" (pp. 24-28).

Girdzijauskaite, E., Radzeviciene, A., \& Jakubavičius, A. (2018). International branch sampus : Sequential market commitment. Journal of System and Management Sciences, $8(4), 57-81$.

Girdzijauskaite, E., Radzevičienè, A., \& Jakubavičius, A. (2019). International branch campus: strategic mapping. In International Scientific Conference: Contemporary Issues in Business, Management and Economic Engineering' 2019.

https://doi.org/10.3846/cibmee.2019.045

Hadley, R. D., \& Wilson, H. I. M. (2003). The network model of internationalisation and experiential knowledge. International Business Review, 12(6), 697-717. Retrieved from http://citeseerx.ist.psu.edu/viewdoc/download?doi=10.1.1.202.1970\&rep=rep1\&type=pdf

Harman, G. (2005). Internationalization of Australian higher education: A critical review of literature and research. In P. Ninnes \& M. Hellstén (Eds.), Internationalizing higher education (pp. 119-140). Netherlands: Springer. Retrieved from http://link.springer.com/chapter/10.1007/1-4020-3784-8_7

Healey, N. M. (2008). Is higher education in really "internationalising"? Higher Education, 55(3), 333-355. https://doi.org/10.1007/s10734-007-9058-4

James, C. L. N. (2009). The internationalisation of Malaysian private higher education institutions for increasing higher education exports (Doctoral Dissertation). Southern Cross University.

Jana, D., Laura, H., Dana, K., \& Clemens, M. (2017). Sustainability-oriented higher education networks: Characteristics and achievements in the context of the UN DESD. Journal of Cleaner Production, (July), 1-14. https://doi.org/10.1016/j.jclepro.2017.07.239 
Jeptoo, M. L., \& Razia, M. (2012). Internationalization of higher education: Rationale, collaborations and its implications. International Journal of Academic Research in Progressive Education and Development, 1(4), 365-372.

Jiang, X. (2010). A Probe into the internationalisation of higher education in the New Zealand context. Educational Philosophy and Theory, 42(8), 881-897. https://doi.org/10.1111/j.1469-5812.2009.00547.x

Johanson, J., \& Mattsson, L.-G. (1988). Internationalisation in industrial systems - A network approach. In Strategies in Global Competition (pp. 287-314). New York: Croom-Helm. Retrieved from http://www.divaportal.org/smash/record.jsf?pid=diva2\%3A45884\&dswid=-6095

Johanson, J., \& Vahlne, J.-E. (1977). The internationalization process of the Firm-A Model of Knowledge Development and increasing foreign market commitments. Journal of International Business Studies, 8(1), 23-32. Retrieved from http://www.jstor.org/stable/254397

Johanson, J., \& Vahlne, J.-E. (2009). The Uppsala internationalization process model revisited: From liability of foreignness to liability of outsidership. Journal of International Business Studies, 40(9), 1411-1431. https://doi.org/10.1057/jibs.2009.24

Johanson, J., \& Vahlne, J. (1990). The mechanism of internationalisation. International Marketing Review, 7(4), 11-24. https://doi.org/10.1108/02651339010137414

Johanson, M., \& Kao, P. T. (2010). Networks in Internationalisation. In J. Pla-Barber \& J. Alegre (Eds.), Reshaping the boundaries of the firm in an era of global interdependence (pp. 119-142). Bingley: Emerald Group Publishing Limited.

Kehm, B. M., \& Teichler, U. (2007). Research on Internationalisation in Higher Education Research on Internationalisation. Journal of Studies in International Education, 11(3-4), 231-239. https://doi.org/10.1177/1028315307303534

Khalid, J., Ali, A. J., Islam, M. S., Khaleel, M., \& Shu, Q. F. (2017). Internationalization as investment for higher education institutions: Introducing a Framework to enhance investment in internalization practices. Review of Social Sciences, 2(2), 1-11. https://doi.org/10.18533/rss.v2i2.87

Kireçci, M. A., Bacanli, H., Erişen, Y., Karadağ, E., Çeliköz, N., Ali Dombayci, M., ... Şahin, M. (2016). The internationalization of higher education in Turkey: Creating an index. Egitim ve Bilim, 41(187), 1-28. https://doi.org/10.15390/EB.2016.6223

Knight, J. (1994). Internationalization: Elements and checkpoints. CBIE Research, (7), 1-15. Retrieved from https://files.eric.ed.gov/fulltext/ED549823.pdf

Knight, J. (1997). Internationalisation of higher education: A conceptual framework. In H. Knight, J., \& de Wit (Ed.), Internationalisation of higher education in Asia Pacific countries (pp. 5-19). European Association for International Education.

Knight, J. (1999). Internationalisation of higher education. In Quality and Internationalisation in Hgher Education (pp. 13-28). Paris, France: OECD. Retrieved from http://ebook.umaha.ac.id/E-BOOKS ON HIGHER EDUCATION/QUALITY _ QA MANAGEMENT, E-BOOK/QUALITY _ INTERNATIONALIZATION IN HE (BUKU).pdf\#page $=14$

Knight, J. (2004a). Internationalization remodeled: Definition, approaches, and rationales. Journal of Studies in International Education, 8(1), 5-31. 
https://doi.org/10.1177/1028315303260832

Knight, J. (2004b). New rationales driving internationalization. International Higher Education, 34, 3-5.

Knight, J. (2007). Internationalization : Concepts, complexities and challenges. In J. J. F. Forest \& P. G. Altbach (Eds.), International handbook of higher education (Vol. 18, pp. 207-227). Dordrecht. Netherlands: Springer. https://doi.org/10.1007/s11618-008-0047-x

Knight, J. (2008a). An internationalization model: Meaning, rationales, approaches and strategies. In J. Knight (Ed.), Higher education in turmoil: The changing world of internationalisation (pp. 19-37). Rotterdam: Sense Publishers.

Knight, J. (2008b). Internationalization: A decade of changes and challenges. International Higher Education, 50, 6-7. https://doi.org/10.6017/IHE.2008.50.8001

Knight, J. (2008c). The Internationalization of Higher Education in the 21st Century: New Realities and Complexities. In J. Knight (Ed.), Higher education in Turmoil: The changing Wworld of Internationalisation (pp. 1-18). Rotterdam: Sense Publishers.

Knight, J. (2013). The changing landscape of higher education internationalisation - for better or worse? Perspectives: Policy and Practice in Higher Education, 17(3), 84-90. https://doi.org/10.1080/13603108.2012.753957

Knight, J. (2015). Updating the definition of internationalization. International Higher Education, 33, 2-3. https://doi.org/https://doi.org/10.6017/ihe.2003.33.7391

Kristensen, K. H., \& Karlsen, J. E. (2018). Strategies for internationalisation at technical universities in the Nordic countries. Tertiary Education and Management, 24(1), 19-33. https://doi.org/10.1080/13583883.2017.1323949

Mader, M., Mader, C., Zimmermann, F. M., Görsdorf-Lechevin, E., \& Diethart, M. (2013). Monitoring networking between higher education institutions and regional actors. Journal of Cleaner Production, 49, 105-113. https://doi.org/10.1016/j.jclepro.2012.07.046

Masum, M. I., \& Road, K. (2012). Internationalization process of educational consultancy firms in Bangladesh: An evaluation. European Journal of Business and Management, 4(7), $34-45$.

Melin, L. (1992). Internationalisation as a strategy process. Strategic Management Journal, 13, 99-118. Retrieved from https://www.jstor.org/stable/pdf/2486368.pdf?refreqid=excelsior:cb9581bf230704877e83d8 bd $7 \mathrm{f} 451757$

Mohd Ismail, A. A., \& Doria, A. (2012). Towards sustainability in Malaysian international education management. Procedia - Social and Behavioral Sciences, 40, 424-428. https://doi.org/10.1016/j.sbspro.2012.03.210

Mohd Ismail, A. A., \& Doria, A. (2014). Finding the next 'wave' in internationalisation of higher education: focus on Malaysia. Asia Pacific Education Review, 15(3), 493-502. https://doi.org/10.1007/s12564-014-9336-7

Mori, K. (1999). Institutionalizing, marketing and networking Asia-Pacific Economic Cooperation (10). Japan: International University of Japan Research Institute Working Paper, Asia Pacific Series.

Mtigwe, B. (2006). Theoretical milestones in international business : The journey to international entrepreneurship theory. Journal of International Entrepreneurship, 4(1), 525. https://doi.org/10.1007/s10843-006-5872-5 
Nguyen, D. P., Vickers, M., Ly, T. M. C., \& Tran, M. D. (2016). Internationalizing higher education (HE) in Vietnam: Insights from higher education leaders-an exploratory study. Education + Training, 58(2), 193-208. https://doi.org/10.1108/ET-08-2015-0072

Ojala, A. (2009). Internationalization of knowledge-intensive SMEs: The role of network relationships in the entry to a psychically distant market. International Business Review, 18(1), 50-59. https://doi.org/10.1016/j.ibusrev.2008.10.002

Paige, R. M., \& Mestenhauser, J. (1999). Internationalizing educational administration. Educational Administration Quarterly, 35(4), 500-517. https://doi.org/10.1177/0013161X99354005

Pinna, C. (2009). EU-China relations in higher education : Building bridges in global cultural dialogue. Asia Europe Journal, 7(3-4), 505-527. https://doi.org/10.1007/s10308-009-0238$\mathrm{y}$

Pretor Fok, W. (2007). Internationalisation of higher education in Hong Kong. International Education Journal, 8(1), 184-193. Retrieved from http://iej.com.au

Qiang, Z. (2003). Internationalization of higher education: Towards a conceptual framework. Policy Futures in Education, 1(2), 248-270. https://doi.org/10.1111/j.14667657.2005.00425.x

Rahim, A. B. A., \& Nizam, A. T. A. (2013). A case study of an internationalization process of a private higher education institution in Malaysia. Gadjah Mada International Journal of Business, 15(3), 211-230. https://doi.org/10.22146/gamaijb.5444

Ramanathan, S., Thambiah, S., \& Raman, K. (2012). A perception based analysis of internationalization at Malaysian private universities. International Journal of Business and Management, 7(4), 13-25. https://doi.org/10.5539/ijbm.v7n4p13

Rastorgueva, K. (2014). Internationalization process of family firms: Reasons, networks and obstacles (Master's thesis). University of Jyvaskyla.

Robson, S., \& Wihlborg, M. (2019). Internationalisation of higher education: Impacts, challenges and future possibilities. European Educational Research Journal, 18(2), 127134. https://doi.org/10.1177/1474904119834779

Russell, E. (2015). The internationalisation of emerging market higher education providers: Exploring transnational provision. International Journal of Business and Society, 16(2), 261-280. Retrieved from http://www.ijbs.unimas.my/repository/pdf/Vol16-no2-paper7.pdf

Ruzzier, M., Hisrich, R. D., \& Antoncic, B. (2006). SME internationalization research: Past, present, and future. Journal of Small Business and Enterprise Development (Vol. 13). https://doi.org/10.1108/14626000610705705

Salas, R. (2014). The rationales and strategies of internationalization in higher education: A comparative study of the University at Albany, SUNY and the University of Oslo (Master's thesis). Universitas Osloensis.

Sanders, J. S. (2018). National internationalisation of higher education policy in Singapore and Japan: Context and competition. Compare: A Journal of Comparative and International Education, 1-17. https://doi.org/10.1080/03057925.2017.1417025

Sarkar, A., \& Perényi, Á. (2017). Education agents as competitiveness enhancers of Australian universities by internationalisation facilitation. Entrepreneurial Business and Economics Review, 5(4), 61-89. https://doi.org/10.15678/EBER.2017.050403

Shahijan, M. K., Rezaei, S., \& Preece, C. N. (2016). Developing a framework of 
internationalisation for higher education institutions in Malaysia: A SWOT analysis. International Journal of Management in Education, 10(2), 145-173. https://doi.org/10.1504/IJMIE.2016.075556

Szyszlo, P. (2016). Internationalization Strategies for the Global Knowledge Society. CBIE PhD Research Series, 1-7. Retrieved from http://cbie.ca/wpcontent/uploads/2016/05/CBIE-research-Szyszlo-PhD-E.pdf

Teichler, U. (2004). The changing debate on internationalisation of higher education. Higher Education, 48(5), 5-26. Retrieved from http://www.jstor.org/stable/pdf/4151528.pdf

Teichler, U. (2009). Internationalisation of higher education: European experiences. Asia Pacific Education Review, 10(1), 93-106. https://doi.org/10.1007/s12564-009-9002-7

van der Wende, M. (1997). Missing links: The relationship between national policies for internationalisation and those for higher education in general. In National Policies for the Internationalisation of Higher Education in Europe (pp. 10-38). Stockholm: National Agency for Higher Education (Hogskoleverket),. Retrieved from http://files.eric.ed.gov/fulltext/ED432190.pdf

Wächter, B. (1999). Assessing the quality of internationalisation: The Internationalisation Quality Review Process (IQRP). In B. Wächter (Ed.), Internationalisation of Higher Education: A Paper and Essay on International Cooperation in the Tertiary Sector (pp. 9598). Bonn: Lemmens Verlags. Retrieved from http://www.acasecretariat.be/fileadmin/aca_docs/images/members/1999_Internationalisation_in_Higher_E ducation.pdf

Wadhwa, R., \& Jha, S. (2014). Internationalization of higher education: Implications for policy making. Higher Education for the Future, 1(1), 99-119. https://doi.org/10.1177/2347631113518399

Welch, D. E., \& Welch, L. S. (1996). The internationalization process and networks: A strategic management perspective. Journal of International Marketing, 4(3), 11-28. https://doi.org/10.2307/25048656

Welch, L. S., \& Luostarinen, R. (1988). Internationalization: Evolution of a concept. Journal of General Management, 14(2), 34-55. https://doi.org/10.1177/030630708801400203

Wendy, W.-Y. C. (2006). The internationalizing of universities: A comparative case study of a British university and a Hong Kong university (Doctoral dissertation). University of Leicester.

Wihlborg, M., \& Robson, S. (2018). Internationalisation of higher education: drivers, rationales, priorities, values and impacts. European Journal of Higher Education, 8(1), 8 18. https://doi.org/10.1080/21568235.2017.1376696

Yat, W., \& Lo, W. (2009). Reflections on internationalisation of higher uducation in Taiwan : Perspectives and prospects. Higher Education, 58(6), 733-745. https://doi.org/10.1007/s10734-009-9209-x

Zolfaghari, A., Sabran, M. S., \& Zolfaghari, A. (2009). Internationalization of higher education: Challenges, strategies, policies and programs. US-China Education Review, 6(5), $1-9$. 